\title{
Tribute to Bach (1956): Approximation to the Oteizian Mural Emptiness as a Silent Music Score
}

\author{
Fernando Echarri ${ }^{1,}$,, Emilio Varela ${ }^{2}$ \\ ${ }^{1}$ University of Navarra Museum, University of Navarra, Pamplona, Spain \\ ${ }^{2}$ Varela Architecture Studio, Official School of Architects Vasco Navarro, Gipuzkoa, Spain
}

Email address:

fecharri@unav.es (F. Echarri), evarela@coavn.org (E. Varela)

${ }^{*}$ Corresponding author

\section{To cite this article:}

Fernando Echarri, Emilio Varela. Tribute to Bach (1956): Approximation to the Oteizian Mural Emptiness as a Silent Music Score. American Journal of Art and Design. Vol. 5, No. 2, 2020, pp. 17-27. doi: 10.11648/j.ajad.20200502.11

Received: May 1, 2020; Accepted: June 9, 2020; Published: June 29, 2020

\begin{abstract}
The artist Jorge Oteiza (Orio, Spain, 1908-2003) is considered one of the main sculptors of the 20th century. Jorge Oteiza won the International Sculpture Prize at the IV São Paulo Biennial, held in 1957, which elevated him internationally. Oteiza's conceptual evolution as a sculptor moves him towards a special relationship with the unoccupied space, the void, seeking a metaphysics of space through absence or negativity, where light also plays a prominent role, being incorporated into the sculptural process. These ideas are concretized in the negative relief mural that he calls Direct Relief / Homage to Bach (1956). This exceptional work from the limited production of his mural works provides an interesting field of study that helps complete the understanding of his thinking and the keys to his aesthetics. Nevertheless, this work is not only close to a plasticspatial dimension. The work also conveys the special relationship of the Oriotarra sculptor with music in general and Baroque in particular and his concern for serialist avant-garde music and its possibility of plastic representation. The present article tries to make an approach to the interpretation of this work, studying in an analytical and synthetic way the artistic, musical and plastic thought of the artist.
\end{abstract}

Keywords: Contemporary Art, Wall, Musical Intelligence, Synaesthesia, Oteiza

\section{Introduction}

It is the year 1954. Oteiza is still an unknown artist. He still has not received the Grand Prix of Sculpture in the Biennial of Sao Paulo from 1957 that would assure his consecration as a sculptor. During a walk around Madrid, the entrepreneur from Navarre, Juan Huarte, discovers and acquires the San Sebastian sculpture by Oteiza, exhibited in the Altamira Gallery (Madrid), which would be the beginning of a long relationship between the artist and the family of Juan Huarte. It would be a friendship that could be described as "patronage" [1] and which went on until the death of the artist in 2003.

In 1956 the sister of Juan, María Josefa Huarte, commissioned the artist to create an exclusively abstract artwork that would later be entitled Direct Relief / Tribute to Bach [2]. By that time, María Josefa had already seen some of the studies and sketches Oteiza had made. She felt strongly attracted to them and decided to place the future work on the wall of her house in Nuevos Ministerios, Madrid. Before its creation, Oteiza evaluates the space, examining the light and its effect on the artwork. The material the artist chose to use is white fine-grained limestone from the Hontoria quarry in Burgos, with an overall dimension of $275 \times 481$ centimeters and a $4 \mathrm{~cm}$ thickness ${ }^{1}$. In the house, the mural fits perfectly between the ceiling and the white stone floor and the arrangement consolidates the piece as a whole ${ }^{2}$. For weeks the mural was made "in situ" ${ }^{3}$. Because of the material, the chosen technique and its dimensions it was considered to be a "rara

\footnotetext{
${ }^{1}$ As for the total dimensions of the mural, if until now we have used the measurements of $272 \mathrm{~cm}$ high $\mathrm{x} 474 \mathrm{~cm}$ wide, which are those of the mural measured when it was between the walls and the floor of the house, here we also have the slightly larger measurements of $275 \times 481 \mathrm{~cm}$ of the mural that is placed and attached to an aluminium frame in the University of Navarra Museum.

${ }^{2}$ In 2014 the work was moved to the Museo Universidad de Navarra [3].

${ }^{3}$ Interview with María Josefa Huarte, in XL Semanal, 22 de febrero de 2009 [2].
} 
avis" in comparison to the rest of Oteiza's artistic production which could be considered rather narrow (Figure 1).

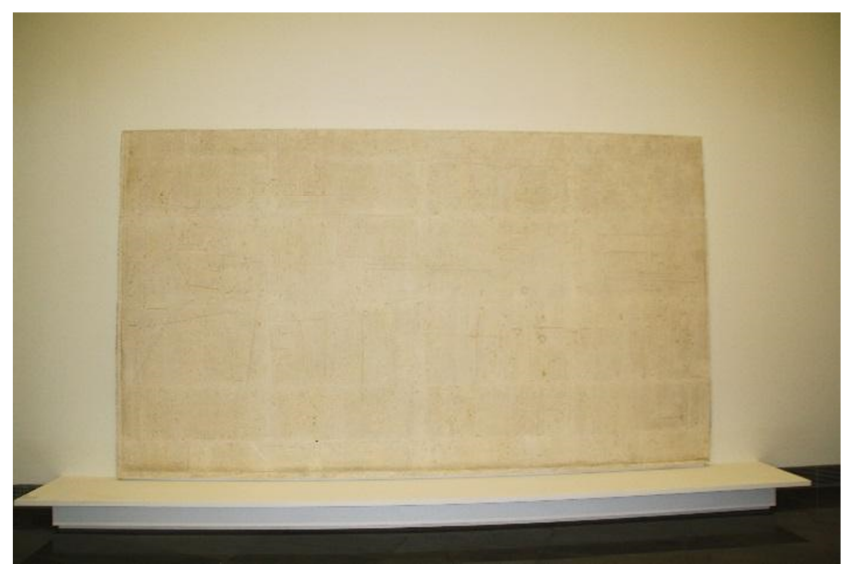

Figure 1. Direct Relief / Homage to Bach (1956) (Photo: Fernando Echarri Archive).

\section{Oteiza's Mural}

Oteiza is aware of the importance of the wall, emphasising it's esthetic power: "Art began in European prehistory when man supported his wounded hand on a wall: discovering the wall aesthetically, the magical power of the wall" [4]. All that is placed on the wall becomes invulnerable, sacred even: "The sacred fountains of life go through the wall, blossoming from the wall into the linguistic flow" [5]. It is not aloof, but knowledgeable of the possibilities the wall possesses [6], which makes him investigate his spatial knowledge, especially through the analysis of Malevich's work.

Between the years 1953 to 1957 Oteiza wrote most of his essays about relief murals, studying the impact that natural and artificial light had on them, on plaster and on the small aerated concrete models, whose material surface was treated by the sculptor with different kind of drillings and castings of a similar nature to the ones made at the time. By then the artist is already immersed in some creative projects of experimental nature that are applied both to his tridimensional and bidimensional space work. In his academic essays Oteiza develops the same layout of the mural as in the volume of the statue. His investigations are aimed at its physical dematerialization, its formal weakening and expressive silence [7]. These are the interventions concerning the wall and the statue that will culminate with its immobility and in the emptiness of space and light.

The sculptor finished his investigations in three works: some transparent glass models, a series of collages; and finally, he set his conclusions on the statue The theorem of cubic idleness*/ Notation for the idleness of the wall [6]. The glass models are made to study what Oteiza would name "wall-light". Through this, on a flat glass between two curves he summarized his idea of the compound wall, a summary of the "Functional extension of the wall" and the "Wall-light" [8]. Oteiza observes "every model with different lightning, artificial light on the side and sunlight from above, the result is impressive. [...] The air has been converted into light. The emptiness, in a spatial body unoccupied and 'breathable' by the shapes [4].

The wall allows Oteiza to include an element that the statue in itself does not allow; the variable of "time". Unlike the statue, which leaves time out and leaves it to the observer, the wall allows its development in the space of its own extension and thickness, and its complete vision of a fixed observer. It is not only its special feature, but also the time which is included in the wall. The most obvious example is that it includes the idea of temporal mobility in its own name, "Slow shapes falling and raising on the labyrinth" (1957). Oteiza intensely studied spatiality of the walls, considering that there is a posterior zone and another anterior to the wall plan. The formal components that the wall contains are floating at different levels, they generate sequences, tension points and they speak in favour of a vacuum space. In this way, the sculptor is able to create a space for reflection. It generates an unforeseen meeting point in the void or, rather, through the void. It provokes an approach to a new space, to a horizon of events, where new experiences can occur. The wall allows the expression of its own space that covers its length and thickness, and its complete vision from a fixed observer. It especially enables Oteiza to precisely organize the shapes in groups and compose wide extensions of the plan with the same techniques of time that were being used in new contemporary music, like the integral serialism ${ }^{4}$ of Pierre Boulez $z^{5}$

Oteiza's wall artwork presents the functional enlargement of the wall, that can contain the plasticity of the musical notes, such as colours, that are none other than the materialization of sound and light. They plastically acquire, not only a time or a duration, but a position in space; and the no-colours, "naked, fundamentally spatial, abstract, unoccupied" [4]. Naked space and color, have the same importance and function as the plastic in silences, absences and gaps in music.

For Otezia there were special colours, fundamentally experimental: black, grey and white; and his position on space defined the sculptor in this way: "The wall is grey. Black is not on the physical wall, it is on the previous wall. The subsequent one is white. The three naked colours, fundamentally spatial, abstract, unoccupied, were specifically ones he later found out that Kandinsky considered to be "non-colours" [4]. The artist also called them that (as designated by Kandinsky). In practice, they could be on the applied materials or on the light, shadowy or dark areas created by the illumination as in the bas-relief

\footnotetext{
${ }^{4}$ Oteiza reflected in the same way on the musical techniques used by Boulez: "When in 1948 Pierre Boulez produced his Second Sonata, he was reasoning spatially about groups that had been serially conceived. The difficulty in reading or interpreting this work comes from the rigour with which the expression has been subjected to the calculation of each site, of each duration, within the first sense of the general circulation" [12].

${ }^{5}$ Pierre Boulez (1925-2016) was a French composer, teacher and conductor. He stood out as one of the main representatives of the aesthetic current of integral serialism. He was one of the forerunners of cultured electronic music and computer music. He had a remarkable influence on the avant-garde music after the Second World War, both as a composer and as a conductor. Wedekind [20] already points to its enabling relationship with Klee's plastic art.
} 


\section{Tribute to Bach.}

\section{Tribute to Bach. Serialism and Wall}

Among the mural artworks of Oteiza, Tribute to Bach (1956) stands out. A negative relief contoured by a set of very subtle clefts in the wall. According to Lizasoáin [9], it belongs to the third type of organisation of mural of Oteiza, characterised by "a clear inspiration in musical compositions" and considers this work to be his most outstanding example.

Oteiza shapes the piece "in situ", live, in real time: "It is formed by working, for a while, blindly but quickly and in the now. I started it in Aranzazu" [10]. Badiola, in his reasoned catalogue, includes the work in the entry of some of Oteiza's creations that contains a direct relation to music, making reference to the special development of the series that will lead to the work Tribute to Bach [11]. Oteiza recalls exhaustively this type of musical expression, making this series of sketches in plaster and collages, for the most part using negative relief on paper, that he will title Exercises of serialism and tensions. Tribute to Bach. This series includes a series of collages with white paper on a white background, in an obvious reference to Malevich and his work White on white (1918). In these collages the elements float in a spatial background and move in different directions, achieving the expressive potential of an empty space and its metaphysical component.

Oteiza will work in this precise way on the "Trials of serialisms for mural treatment" and his "musical series" of 1955-56 (Figures 2 and 3), taking into account the experimental techniques of those musical compositions, especially of the German composer Karlheinz Stockhausen who, during that period, like many other musicians -such as Boulez-, were applying and developing in their own compositions [12].

For his mural studies in plaster he will use little rectangular plaques of approximately $20 \times 30 \times 2 \mathrm{~cm}$, made in plaster casts and forged in aluminum, in a horizontal format. He illuminates the plaques from different angles to check the behaviour of the mural's shapes and calculates the angle on the face of the empty polyhedrons sunk in their own thickness (Figure 2, Figure 3).

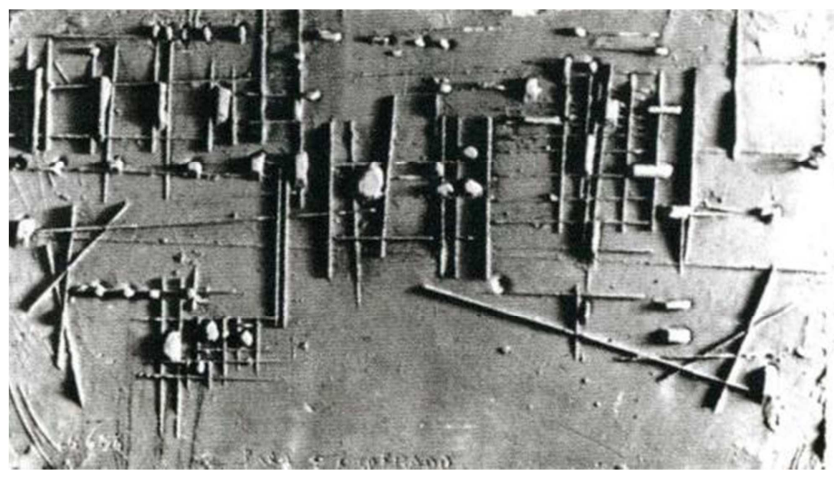

Figure 2. Relief from the series Exercises in Serialism and Tensions. Tribute to Bach (1956). (Source: Oteiza, Egg aesthetics. Egg and labyrinth, 1995: 64).

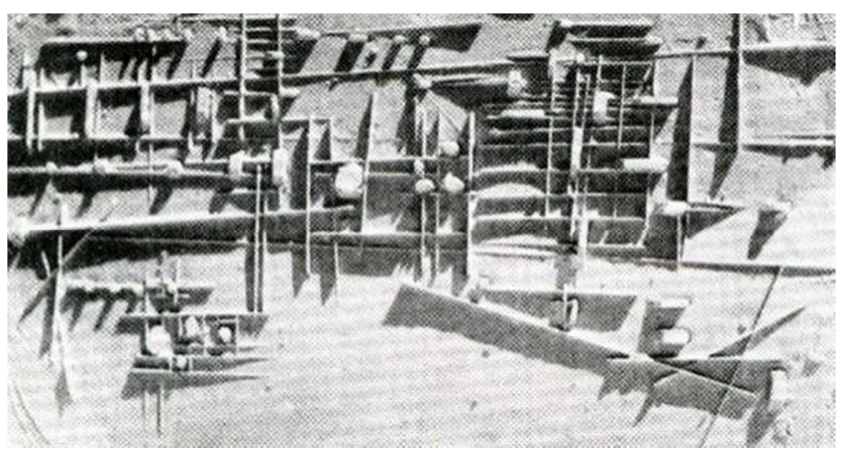

Figure 3. Relief from the series Exercises in Serialism and Tensions. Tribute to Bach (1956) under different lighting. (Source: Oteiza, 2007. Floating dynamics and application in architecture).

Of them he comments "rhythm, light, composition, serialism, some plaques were true musical scores" [10]. The lines in these tests are organized to represent rhythms, durations, silences or voids. Oteiza will make linear incisions and small volumes that, due to their shape and arrangement, suggest a musical language.

In this series of reliefs, the formal components are silenced in favor of spatial behaviour. In this way, it creates a vibrant surface, sensitive to small changes in light, especially shallow light, which makes shapes move forward and backward, achieving a slow and smooth transition of shadows, thus stopping the speed of light, converting the wall in a permanent, but slowly variable, container of light (Figure 4).

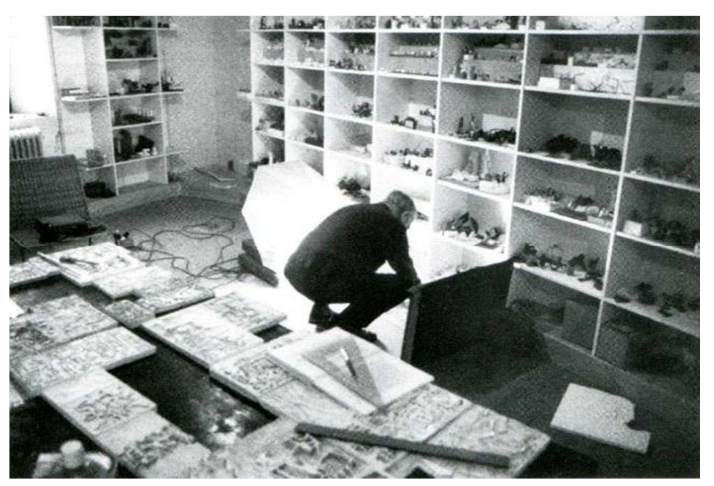

Figure 4. Oteiza in his studio doing light tests with lamps and reliefs. (Source: Oteiza Museum Archive, 2013: 123).

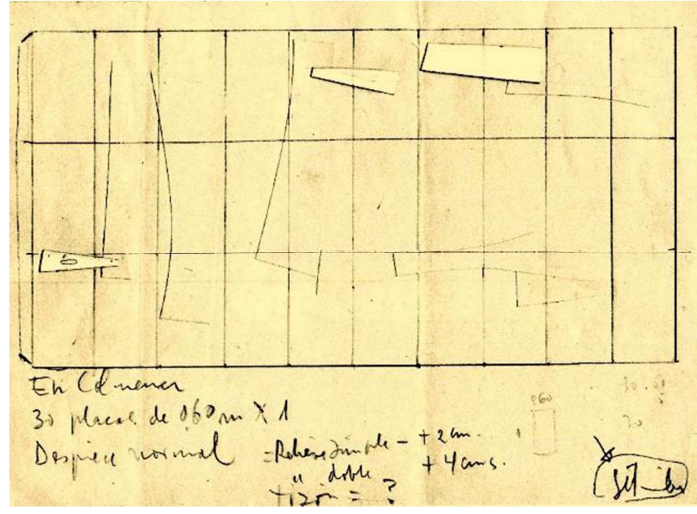

Figure 5. Preparatory drawing for the wall relief Tribute to Bach. "Despiece" (1956). Collages of paper and pencil. 23,2 $x$ 32,7 cm. (Source: Badiola, Oteiza, Reasoned catalog of sculpture, 2015: 474). 


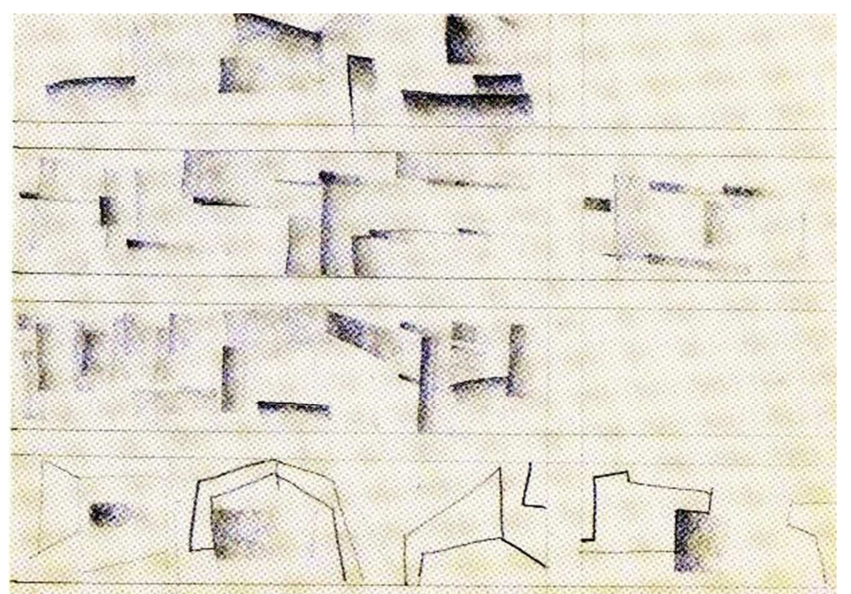

Figure 6. Preparatory drawing for the mural relief Tribute to Bach. "Colisiones y desplazamientos" (1956). Collages of paper and pencil. 23, $2 x$ 32,7 cm. (Source: Badiola, Oteiza, Reasoned catalog of sculpture, 2015: 474).

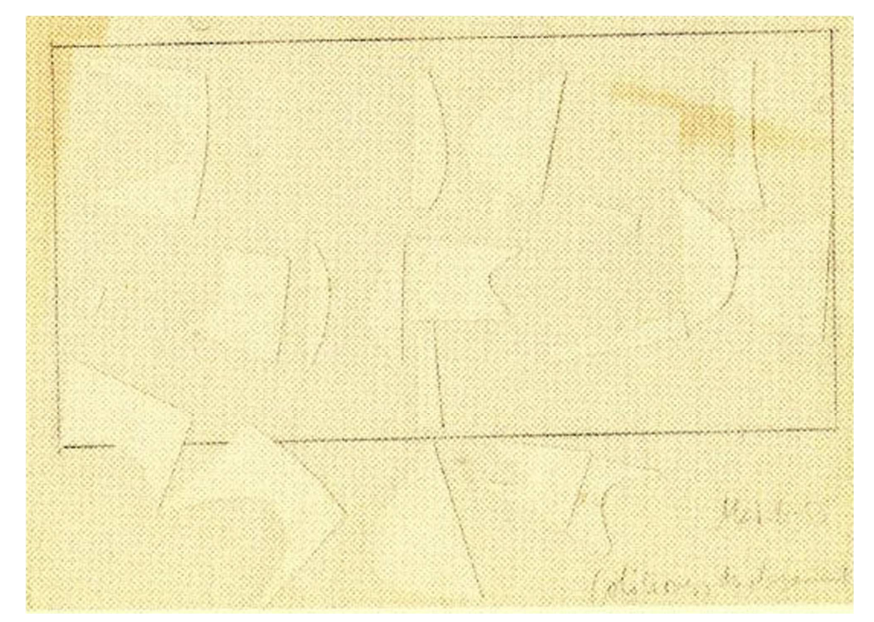

Figure 7. Study of relief for "Tribute to Bach", 1956. Pencil on paper. 22,5 x 32,3 cm. (Source: Oteiza Museum Archive, 2013: 232).

To place Tribute to Bach in its place, the sculptor made a series of sketches and analyses of the house [7], studying the different points of view and the entry of natural light into the space [1], and evaluating their possible incidents in the vision and final perception of the work ${ }^{6}$. Furthermore, through different sketches and collages, he will write down measurements of the dimensions of the mural - which occupied the entire wall, of the type and exploded view of the stone $^{7}$ of the thickness of the slits. He will carry out some tests with the main elements of the composition in cardboard cutouts of a colour and tone similar to that of the stone; They become a kind of sheet music that would serve as sketches so that, once the bare pieces of the mural were installed on the wall, the relief would be executed directly by carving into the stone (Figure 5, Figure 6, Figure 7).

\footnotetext{
6 "Oteiza carefully studied the effect of the natural lighting on the mural, which came from a window on the right, in such a way that the light materialised the presence of the subtle incisions" [6].

7 "The mural relief Tribute to Bach suggests a large score, in which the sculptor... has intentionally divided the stone into the five horizontal lines of the pentagram (the still)" [6].
}

From this series of sketches, Oteiza tackles the mural commissioned by María Josefa Huarte, made up of 36 stone modules $^{8}$. Working with pointers, chisels and scratchers, he intervenes directly on the wall with slight linear incisions and hollows in the form of empty polyhedra that are embodied by the variable intervention of the grazing light coming from the window located perpendicularly to its right.

The Tribute to Bach $^{9}$ mural, however, derives its depth and sequence, not from the real colours of the stone, nor from the flat geometric shapes circulating in the extension of the wall, but from the light and space that the artist achieves from the emptying of the stone, with the intention of dematerializing and lightening the physical plane of the wall, which without the weight of colours and shapes, activates the spatiality not only of its surface but of the space where it is located. Oteiza tries to separate the gravity granted by the lines of the static pentagram from the groups and elements that make up his mural, which acquire a floating and even expansive character, in their three-dimensional spatial character.

Previous research into the spatial nature of the wall indicates that Oteiza called these works "lightweight walls" ${ }^{10}$. The sculpture was made of solids, open to space and light by geometrical openings and by punctual and linear perforations, such as "open polyhedrons" and "light modules", aimed at weakening their mass in order to gain spatial energy around the statue. This flatness and extension of the wall allows it to develop all the plastic potential of the statue, through time, in the form of series or sequences of empty and immobile elements, but active in space (Figure 8).

The work, already indicated via its title, is a tribute to the genius of baroque music, Johann Sebastian Bach, although the plastic formalism it contains is more related to the socalled contemporary classical music and its writing. Oteiza always felt connected with the work of the composers Arnold Schönberg ${ }^{11}$ and particularly with that of his disciples, Alban Berg and Anton Webern [12]. They worked first on free atonalism and then on dodecaphonism or dodecaphonic serialism, seeking a "musical language revolution" [13]. Oteiza collects this musical form and relates it to aesthetics [14]. In the tests of Exercises of serialism and tensions, the sculptor will try a type of graphic notation from linear incisions and small volumes that suggest linkages, rhythms, durations, gaps, intensities, which closely connect it with the type of musical notations that were practiced by the creators of contemporary music of the moment.

\footnotetext{
${ }^{8}$ It's really 36 and not 33, as shown in F. J. Roldán y E. Martín [3].

9 "Johann Sebastian Bach is the Baroque composer that most interested Oteiza and considered that his influence extended to the 20th century [6].

${ }^{10}$ The term "Paredes livianas" (Light Walls) appears in Oteiza's writings when he refers to a series of reliefs that he worked on throughout 1956, considered by him to be his most intense period of experimentation and work. These are intermediate works between those that he carried out as an occupation of the wall and those clearly spatialist ones that Oteiza proposed from 1957, as a result of his sculptural experimentation. In them, his intention to lighten the wall as much as possible is clear, and this is what is new, taking into account the space in which they are located" [7].

${ }^{11}$ Scönberg is considered the "inventor of the dodecaphony" [13].
} 


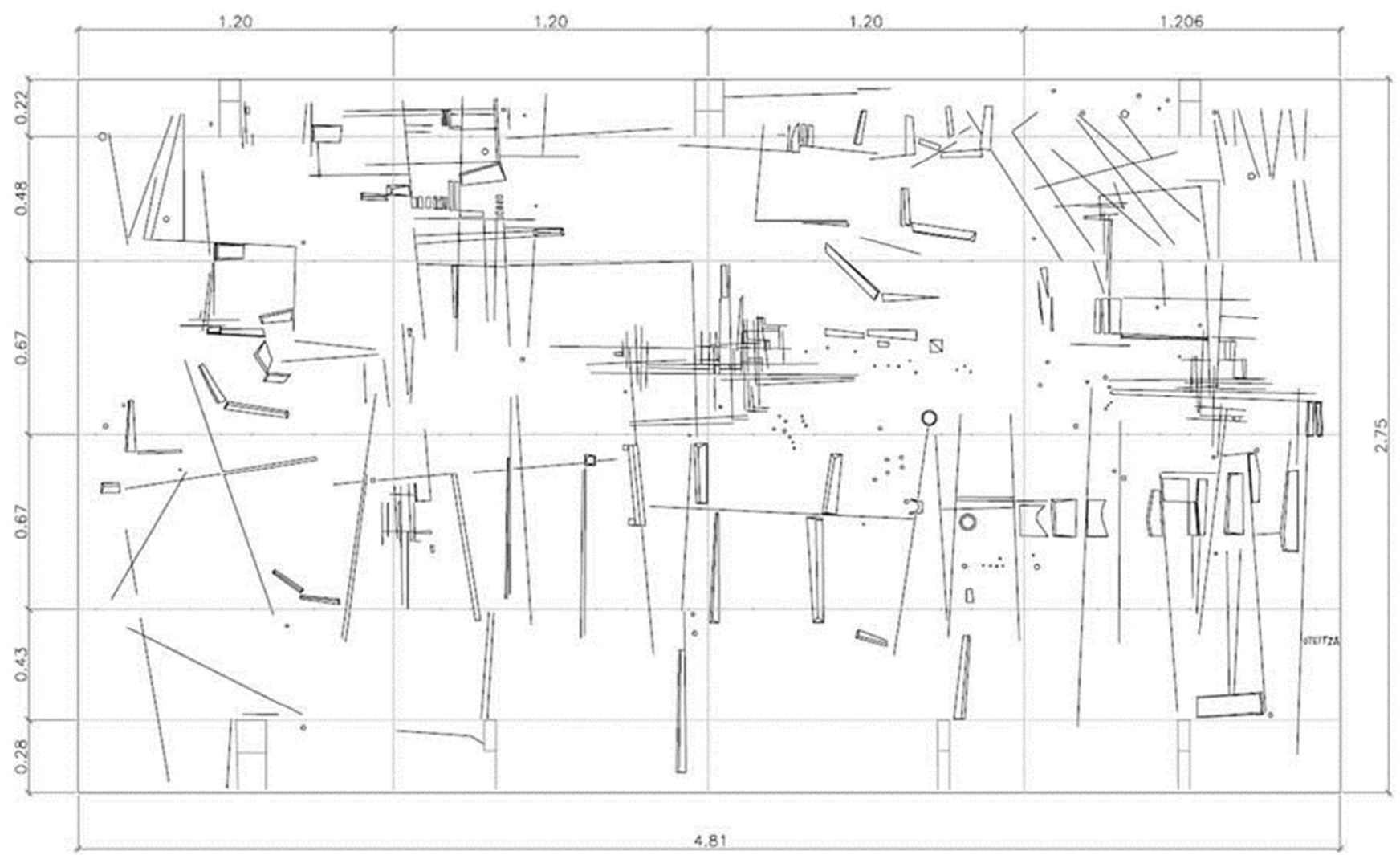

Figure 8. The mural Tribute to Bach has been drawn in order to better appreciate the position of its elements, the distribution of the areas and groups with greater and lesser spatial activity and the formal composition in series of points, lines and surfaces due to the extension of the wall. In addition, the stone's pebbles and its dimensions have been drawn in a lighter grey. (Source: Emilio Varela Archive).

In Tribute to Bach, in his intention to understand reality, Oteiza delves into his "interest and research in the concept of space, light and the wall" [1]. The work expresses Oteiza's concerns in two fields, synergistically: the plastic and the musical. Oteiza pays tribute to Bach, but using the plasticmusical aesthetic that serialism provides him. Basically, the permanent Oteizian intention to reach through these languages or artistic expressions to the spiritual is kept in mind: "It must be borne in mind that the final purpose of Oteiza's sculpture will be the search for an immobile, silent and spiritual before which the viewer must be concerned" [6].

\section{Tribute to Bach and Light as Interpreter of a Silent Score ${ }^{12}$}

The play of light on the wall is essential in the work. In its original location, the mural was next to a perpendicular window just to the right of it. In this way, natural light bathes the entire wall and forms a surface very rich in textures, because it discovers and includes the porosity that the wall itself has, discontinuities in its surface, different imperfections. Oteiza sees them, respects them, sculpts

\footnotetext{
${ }^{12}$ Oteiza uses the term "silent score", "I can turn a hell of a movement, lights and noises, into an ecological work of art, an unbearable city into an ordered film with its composite language that I can even reduce to a silent score" [9].
}

others, including holes, lines and figures. Many of these figures contain asymmetrical undercut bevels, which slow the transposition of moving light.

He could have used symmetrical bevel grooves or at the same depth, but it's not the formula he uses. Thus, Oteiza is intervening in the speed of light, causing the light to change speed. He created transitions with which the darkness is played with. It achieves something like what Oteiza mentions in reference to his glass works: a wall of variable light in which "the shadow grows or decreases, becomes more intense and is completed by a mysterious area of semidarkness [Here the forms] They live, they move, they express themselves and define" [4]. The wall contains the three Oteiza colours. Those are the colours found in nature by light. The duality of light seeks it, making clear the thesis and antithesis it contains, just as sound contains the antithesis of silence. The relationship with music is clear. In the composition of Tribute to Bach, instead of playing with notes, he is playing with Oteizian colors. Oteiza uses his already mentioned three naked colours: white, gray and black, but generates a great variety of grays on the wall according to the life that the light gives them. The mural contains scenes of groupings of fragments that allow us to appreciate in detail the geometric shapes used by the sculptor due to the incisions in the stone plates, made as a function of space and light (Figure 6). Oteiza sculpts "rhythms, cadences or counterpoints marked by systems of lines, fine or thicker, 
sunken or protruding, with greater or lesser depth, organised in families or independent [...] Oteiza manages to lock a plastic composition in the plane by means of a dynamic and harmonious system [...]" [9]. This contributes to the composition of different movements and tones from the depths and inclinations of their planes towards the interior of the stone. (Figure 9, Figure 10).

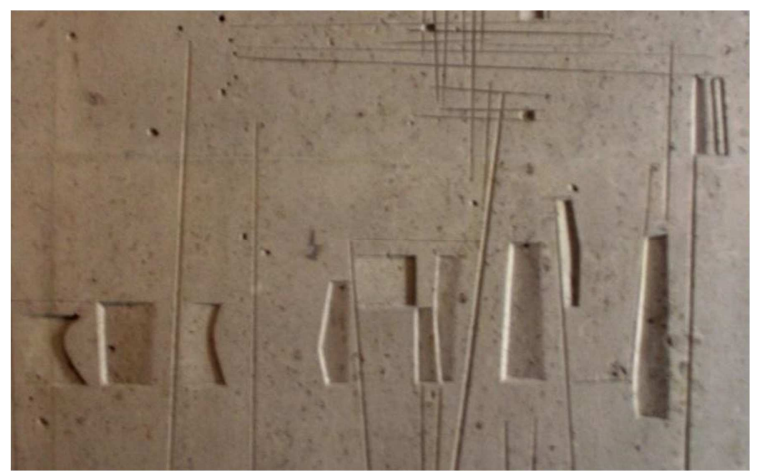

Figure 9. Detail of the artwork Tribute to Bach (1956). (Source: Fernando Echarri Archive).

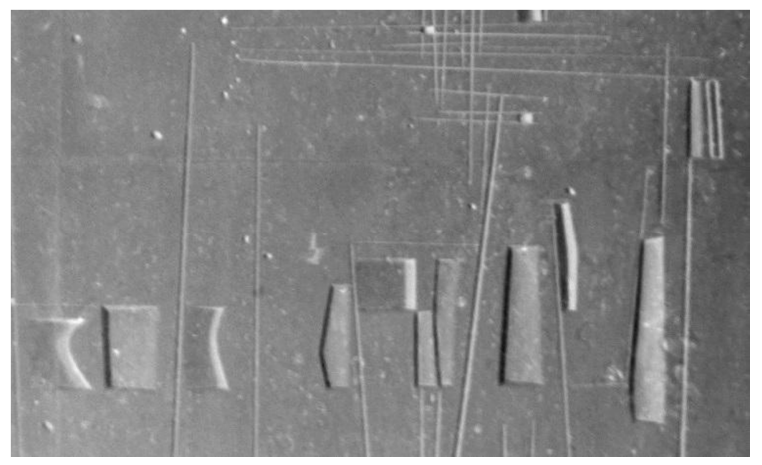

Figure 10. Detail of Homage to Bach inverting the grey scale. (Source: Fernando Echarri Archive).

The same fragments of the mural like inverted images, in negative, could illustrate, by way of radiography, what happens inside the stone (Figure 7). They somehow provide visibility to the immaterial, turning shadow into light, emptiness into fullness, and space into matter. Oteiza closely studied the incidence of natural lighting on the mural, in such a way that the light materializes the presence of the subtle incisions. Incised lines move or create stress points. Trapezoidal shapes and polyhedral constructions are also observed to move, recede and are suspended in the space behind and before the wall, due to the effect of the light. As Oteiza explains in his glass models for the study of the lightwall, possibly the forms of Tribute to Bach behave by the effect of light as a living being, as a purely spatial organism. The wall constitutes a visual metaphysical score. It is qualified as metaphysics because it is composed with the potential of the language of silence, the antithesis of sound, of what goes beyond the physics that contains matter, of nonmatter, of metaphysics. The wall in reality is immobile, just like a musical score. But Oteiza gives light an active role, the role of conductor and visual interpreter of the metaphysical music that the wall-score contains. A score that does not have a mechanical hold over the writing from left to right. Light is the interpreter that sets the necessary rhythm for visual listening, a recurring silent interpretation of the circadian rhythm.

One could say that it is like a musical-instrument-score, that when it is touched by light, that it makes, unlike a musical instrument, vibrations of light and not wave sounds. The wall becomes an instrument or silent score of absences and vacuums ${ }^{13}$ that, depending on the light, can change the physical and solid level of the wall. It materializes and empties, it creates light, through different holes and spaces in the stone, that the artist measures, like a composer before executing his music. Thus, different areas and levels of shadow are produced that provide the different shades to the stone that complete the vision of the work.

\section{The Hyperspace of Tribute to Bach}

The Tribute to Bach relief would be for Oteiza an attempt to achieve an "empty wall" [14], unoccupied, very different from the "mass wall" of previous works such as the frieze on the Aránzazu façade. For Oteiza, Bach is synonymous with popular art, similar to the one he would like to develop in the Basque Country. And the mural, a way to return to monumental art which it is, in the contemporary world, Mexican murals or Picasso's Guernica, or as cave painting was" [14].

Oteiza considers that "The public development of a work depends on the laws that govern the space, which must be calculated and transcended, so that the viewer [...] is not independent of the mural's spectacle. the viewer is trapped, actively included in the composition [...]" [15]. In this sense, the new art that Oteiza promotes requires a new spectator, who will not find a single point of view of the work, but rather "the mural centre is multiple and the spectator finds it wherever it is located [15]. In Tribute to Bach the position of the spectator is key, because he interacts through his gaze with the light projected from the work, and that light will be different according to the position of the spectator and according to the time of day when the work is viewed. The scale of what is seen, of what is looked at, also has its importance. The viewer moves and stands to look. There is a place and a moment when the space of the mural comes to you, a place where the immobility of Oteizian hyperspace is achieved. The viewer has already been pierced, has been included in the work, is within its energetic area of influence, within the wall. The viewer no longer dominates the work. It is the work that allows you to enter it to show you its secrets. Once inside the spatial fragments appear. It is no longer a whole, fragments appear in the form of silent music-plastic scenes. That is why the gazer before the Oteiza wall has to unlearn seeing in order to learn to look in a different way. That looking cannot claim to recognize, for

\footnotetext{
13 "I can turn a hell of a movement, lights and noises, into a work of ecological art, an unbearable city into an ordered film with its composite language that I can even reduce to a silent score" [9].
} 
example, a musical language. You can only pretend to have an open mind to what the work wants to show you, to become aware of the world that the work itself is showing you. It is the experience of the work, which is produced from the visual, but which goes much more than the visual because it encompasses all the senses in the artistic experience, for example listening to the different and changing plastics silences of the work, in a kind of synesthesia, since Oteiza tries to "see and hear sound, colours and space" [12].

The spatial fragments that Tribute to Bach contains are not limited to being mere readings on the plane, but the variability in the density of the shapes suggests a possible depth, a three-dimensional scale that from the background advances towards the space of the spectator, in what which is guessed as a possible three-dimensional piece of music that arrives with different scenes at different times to the viewer. The position of the lines has its reading too. It is not a Mondrian work with the patent balance that exists between its lines. The lines of Tribute to Bach suggest movement; it contains an instability that makes them move. It is the movement that the musical nature implies. It is the music that a sculptor performs with the means he has. He is a sculptor who tries to make something visual that is not visual.

Oteiza thinks seriously about the possibility of representing music with the sculptor's own means, obviously not through the staff, although in the Tribute to Bach the horizontal cutting of the stone reminds us of this [6], but from a notation created from points, lines and surfaces perforated in the wall, which he was already using in the sculpture. He uses a set of plastic and geometric elements to compose an original sound space or visual music, which consists of the combination of different vibrations, pulsations, palpitations and oscillations produced by the incidence of light on the forms. In this way, it creates spatial and luminous forms that distribute their shadows over the entire extension and depth of the wall plane (Figure 11).

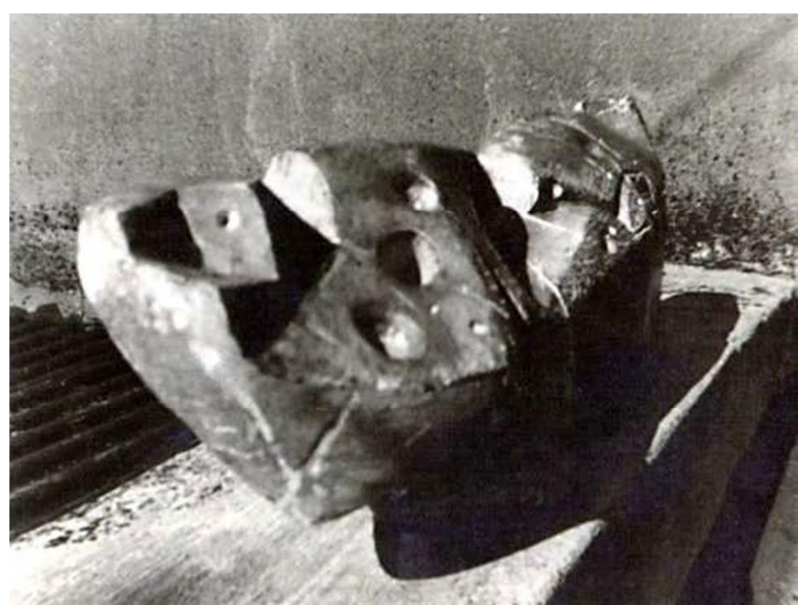

Figure 11. Woman lying down / Tribute to Bach, 1947. Oteiza had already related his surface treatments to the statue with music. This is shown in this sculpture, which presents different interventions, emptied from dihedrals and trihedrals with different orientations or punctual and linear perforations on its surface, which the sculptor will repeat later and probably with the same intention in the mural Tribute to Bach. (Source: Badiola, Oteiza, Reasoned catalog of sculpture, 2015: 101).
In this sense, the sculptor raises as a possibility of graphic representation of music the piece, Composition in black and white (1917), by Piet Mondrian. It is no coincidence that he resorts, as on other occasions, to the work of the Dutch painter. This is a work of a geometric and experimental nature, carried out in a series of spatial compositions and with a manifest interest in music. On this occasion, Oteiza draws in a small sketch an outline of this work with + and signs inside an oval, accompanied by an annotation that says "PM is neutralized in 1917" [12], referring to the Dutch painter and this work, which for Oteiza supposes a state "in the second phase of expression" as an empty end or visual silence.

Mondrian makes an oval composition from small vertical and horizontal lines that intersect, forming groups of asymmetric crossings and empty areas, but with active energy, positive and negative, in space. Simple lines that in their central part are more precise and tight, and that dissolve and separate, like sounds in the air, as they move towards the background and the edges of the composition. The sculptor identifies them with plastic elements, graphic signs, whose main aesthetic function would be to regulate the levels of expression: "In this oval, with two areas covered with signs ( + and - ) of different density, the breathing (already light, as if fading...) of the expression is perceived" [12].

The sculptor recognizes in this piece, and points out in his notes, the capacity of signs to represent the space in an elemental way. Not through the visual method of perspective, but through its sonority, regulating the volume of visual sound and silence of the composition from areas with different levels of density (+ -). With this, he measures, as if it were sound, the exact position of the shapes with respect to the empty and silent physical plane of the wall. Thus, it gives the work a sound dimension that comes from the pulsations and oscillations of the forms in the empty background of its space, which defines, for the sculptor, his own "spatial breathing" [12]. The more shape, the more image in the work, the more noise and less visual silence. The greater the absence of form, the greater the active spatial energy of the work. Thus, in this way the work functions as a measure of expression, in this case, for the progressive silencing of expression.

\section{Some Musicological Keys in the Interpretation of Tribute to Bach}

Oteiza is a complex and multifaceted artist, a multidisciplinary creator with a sculptural work of evident importance for 20 th century art. He is a "creator who naturally contemplates the translation of concepts and ideas between the arts" [12], for example music ${ }^{14}$. For Oteiza, music is the art that most easily accesses the spectator's

\footnotetext{
14 "Painters and musicians have always found inspiration by sharing ideas from both disciplines" [21]. Por ejemplo, "Klee implemented his idea of "polyphonous painting' in in countless works, not only in those including references to contrapunct in their titles. He translated contrapuntal practice and canon" [22].
} 
emotions, but it is the most difficult art to be able to achieve fully [12]. That is why Oteiza investigates music as an artistic language and some of its great teachers, "those who created a school and those who advanced the history of western music, the composers who changed the course of music and those who established European tradition" [12]. He was also attentive to the avant-garde, such as the Serialists, paying special attention to the twelve-tone ones. It follows the great names of musical composition from 1945 such as John Cage, Pierre Boulez, Karlheinz Stockhausen and Luciano Berio. From them more names emerged, like Schönberg ${ }^{15}$ and his disciples Alban Berg and Anton Webern [12].

Johann Sebastian Bach is the Baroque composer who most interested Oteiza and considered that his influence extended 6until the 20th century. That is why it connects him to Schönberg and his twelve-tone school, pantonality and jazz. All were "indebted to a Bach who makes diatonism reenriched by polytonality, the cult of strict forms and logical musical structure. Bach combines horizontal writing with a then novel verticality, with the counterpoint, which Oteiza considers 'a place of privilege' and polymelody" [12]. Oteiza's admiration for the musician from Eisenach (1685750 ) is evident, not only for the dedicatory tribute that this work represents, which could even be considered as a monument to Bach, but Oteiza, aware of the spirituality contained in his music, chooses Bach also to represent the spiritual search that Oteiza develops in his plastic work.

The Tribute to Bach relief is an exercise close to contemporary music and especially to Arnold Schönberg and his twelve-tone serialism [12]. This expands the creative possibilities that affect the musical measure or meter, the rhythm and especially the silences. For Oteiza "dodecaphonism is the abstract approach to musical problems, it is music considered as an independent reality and necessarily of a spatial nature" [12].

The connection of this contemporary music with the music of the past, specifically that of the 18th century, is a recurring idea to Oteiza: "in the past we have religious monuments of music that from our preparation in current music, we get a deeper understanding of our music from the past which enriches it." [12]. "I even believe [...] the only thing necessary is to turn a little to lean on Anton Webern and dive into 18th" [12]. From these considerations it can be deduced that Tribute to Bach suggests a great score that honors Bach from the plastic-musical aesthetic that serialist language can provide.

For Oteiza [12], both concrete and electronic music respond to a concern for spatial occupation-unemployment, as well as with his metaphysical awareness of space and with his ideas about spiritual service and the aesthetic approach of contemporary art. Maybe that's why one chooses negative relief. The mural presents an anti-score, a music from the void, a metaphysical music represented in silence. Oteiza can

\footnotetext{
${ }^{15}$ Many of them like Cage and Schönberg in turn showed interest in plastic art, as proposed by Kandinsky or the group of American abstract expressionists [23].
}

collect the plastic-musical duality in the same sculptural work, where the music does not sound, but exists, like the worldly music of the Pythagorean theory [16]. In the musical fabric [17] that this score shows, some musicological keys could be found, as a "composition anatomy" [12], which are represented in textural values such as height, axes, simultaneity, time, sequence, tension, rhythm, proportion, movement, developments, hierarchies, etc. [18]. The following are described below.

\subsection{Plastic-musical Spatialism and Structural Fragments}

We know that we can get closer to the way Oteiza listened to music. Or at least one of the ways. It was to make a "visual translation" of the music [12]. And that translation is done through the serialization of minimum units that Oteiza calls sonema:

"A phoneme, I think, let's imagine for short a finger, a finger in the active sentence of my hand. If they take a finger away from me and examine it like this, scientifically isolated and alone, it is my finger-phoneme. But if I recover it, it works again, it participates in the multiple life of the hand, the phoneme sounds again with the world of sounds, in the world of images, it recovers its aesthetic nature with life. I have to call it different from phoneme, it sounds to me and it responds perfectly if I name it Sonema." [5]

It is possible that this musical translation is the one represented in Tribute to Bach. We find an "artistic object" that can harbor musical attributes for "its movement and its stillness, its rhythm, its static, its dynamics, its cadence, or its way of modifying the sound that runs through it inside and out" [12]. Fragments or groupings appear in the work, that which Oteiza calls structural centres or rhythmic cells, where changes in density appear that make them understood as sound quantity per unit of time [12]. Oteiza gave importance to this unit, perhaps included in the structural fragments of rhythmic cells that develop along the 36 pieces that make up the Tribute to Bach mural, divided around five horizontal lines, perhaps as a unifying pentagram. As Martín [6] indicates, this staff would represent the immobile, compared to the different elements included in the mural, that give it its dynamic character.

The mural has a musical architecture where we must discover its mechanism and logic [12]. For a true understanding of music it is necessary that we distinguish its material body. As in all art, this material body is Space. Because music participates in the same plastic nature as sculpture or painting, the choice of the form and mechanism of the space "is the composer's personal work. It is a principle and a particular result in each work [...] it contains the spaces and the sound geometries with their units, in a static offering arrangement [...] Music is seen as one can see a statue, it participates in its very plastic nature, because listening to music is to reconstruct the geometric scheme on which it rests, and to gradually capture fragments of the musical space of the work [...] Music is not heard, it is seen" [12]. In a synaesthetic vision, he believes that the "avantgarde musician tries to see space but not with his sight, he 
continues to see with his ear, he does not hear space well because space is heard with visual perception" [12].

Oteiza considers that we should see music in a plastic way: "If we are not saving, as a piece of music is heard, geometric accidents to in the end reconstruct in our hands a polyhedron of lines or times and vertices or figures, of spaces or plurisonous extensions, we do not know what we have heard. If we do not see what we have heard, we do not know what we have heard" [12]. Tribute to Bach is a way to retain musical memory. The staticism of the gaps in the wall has inscribed the metaphysical score in memory. For Oteiza, the twelve-tone procedures are vertical, which supposes a primacy of the spatial [12]. It is spatialistic in terms of "cuts, discontinuity, setbacks, opposite planes (near-far), collisions, turns, overlaps or brakes" [12]. And he considers the vertical as "contrary to discourse, to time, to the horizontal succession of melody". In this way Oteiza reasons with the geometry of space and with the geometry of time, although he considers them inseparable [12].

\subsection{Sound Lines and Surfaces}

Oteiza presents "a conception of sound in which lines and surfaces generate sound volumes. The notes are simple sounds, fundamental units that become by their temporary existence in vertices of a line" [12], such as those contained in Tribute to Bach. A held note is just a straight line [12], it is stretched by time only in the same direction, and will fall back on another line if another one with a higher velocity sounds in parallel. The combination of notes and beats or rests between notes will result in straight or curved sound lines. Applying this idea, the notes in Tribute to Bach could not possibly be variable because they are not curved. For Oteiza curved lines are the variables in intensity that time converts to surface. Oteiza takes into account the influence of verticality on the sound lines: "A sound line is considered to go backwards, when another one of higher speed moves in parallel [...] A note is said to go backwards, when the following figure is written or drawn - chosen - by the composer on an upper floor" [12].

\subsection{Sound Volume}

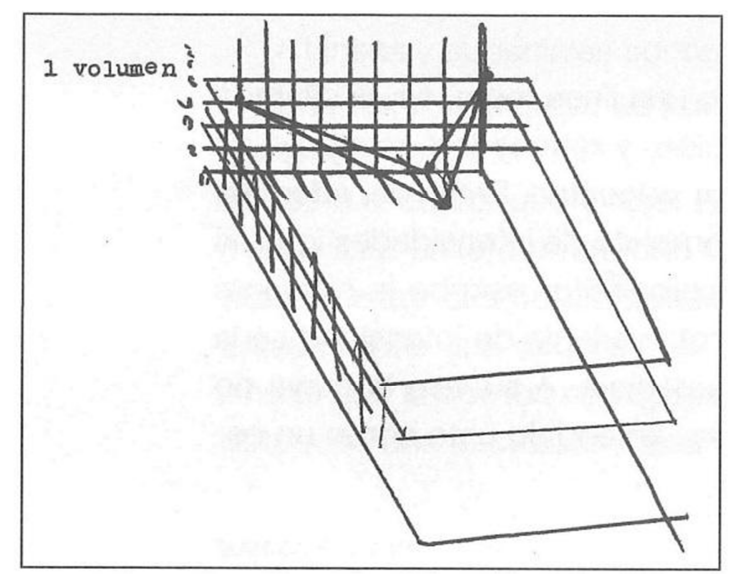

Figure 12. Volumen sonoro dibujado por Oteiza. (Source: Oteiza Museum Archive. FD-5172).
For Oteiza the sound volume does not refer to the sound power, but "to the plastic idea that a sound volume is generated when two different lines concur at the same vertex" [12]. In Tribute to Bach, it is the viewer's gaze that establishes the sound volume, with the two lines it draws, according to their position in front of the mural (Figure 12).

\subsection{Time}

For Oteiza "time, tempo, space and silence are aspects of recurring interest [12]. Oteiza considers four types of times in art. "Outside the work there are two species of time: the interior of the human being and that of nature. On the other hand there is the timeless condition, the time equal to zero, and finally the internal time of the work [12]. In Tribute to Bach the time is different. The time that appears in Tribute to Bach suggests that Oteiza is using in his plastic music a spiritual and metaphysical time [12], he is looking for time equal to zero, the time that would correspond to an eternal homage to Bach, to spiritual music located in the space of timeless silence provided by the wall. Its gaps are static, although they change with light, so natural time, that of the real world [12], also appears.

For Oteiza it is a mistake to consider music only as a temporary art [11] because every work of art has a spacetime nature. But it advances further in the case of baroque music, considering that in it "Time is detached from Space [12]. When Time is removed, sacred space is achieved. That is what he has achieved in Tribute to Bach. Perhaps in this mural Oteiza's intention manifests itself: "the suppression of Time and the concept of immobility by which I arrive at spatial unemployment by the reduction of form, of formal spectacle, to pure spatial consciousness" [14].

\subsection{Rhythm}

Oteiza considers rhythm as an important quality of music and one that unites it with the vital pulse, considering it as "the nature of nature" [12]. It values the contribution of the Baroque in the recovery of rhythm, facing the Renaissance that its containment represents [12]. As mentioned, the contents of the mural can be grouped into minimal rhythmic cells that change in density, which could be musically understood as the sound quantity per unit of time, as occurs for example with the central cell of the mural, which contains an obvious density. The different density of its cells gives the mural a property that in Oteiza's words, we could call "rhythmic respiration" [12].

\subsection{Harmony}

In Tribute to Bach, we could interpret that there is a simultaneism of harmonic planes like the one described by Oteiza when speaking of Schönberg [14]: "Simultaneism of harmonic planes, I break the style of temporal continuity with superimpositions, simultaneous harmonic planes, providing a spatial concept against the traditionalist temporal concept". 


\subsection{Tone}

For Oteiza the tone is the mass [14], the centre of gravity, as he suggests when he talks about Wagner [12]. In tonal music, both silence and pause are closely related to rhetoric, since they often find meaning through their relationship to musical or linguistic parameters of expression. In this sense, it could be said that the work Tribute to Bach contains a central tone, which gives it the densified central fragment.

But this possible interpretation contrasts with another possible one, which points to Oteiza's plastic interpretation towards the serialist music that is collected in Tribute to Bach. This interpretation suggests an atonal work. This atonality could be represented in fragments or open cells of variable gravity, not spatially accentuated [12], contained in Tribute to Bach.

\subsection{Timbre}

Oteiza transposes what Schönberg calls "ring melody" [12] to silence. With timbre melody Oteiza refers to a compositional technique by which the melody is created through sound colour-timbre. In Tribute to Bach that sound color could be realized by the changing colour that the light constantly gives to the mural. It is strongly evidenced that if contextualized in atonal and athematic music, this relationship changes in its role in the articulation of the structure and architecture of the work, as well as in the attention and emotional reaction of the listener [12].

\subsection{Silence}

In different annotations by Oteiza, his concern for this subject reoccurs [12], perhaps because he analogizes it with the void, which is so powerful in his work [14]. For Oteiza, silence is like a fourth dimension of language [14]. The form originates in spatial silence, which is the active void, the negative form, because the volumes are positive and the voids are negative [14]. Silence is "a pure time or uninhabited course" [14]. Silence is an element that, in the field of musical rhetoric, is often related to eternity or death. According to the design of the work, the structural centres of Tribute to Bach mark a composition that includes silences that do work, in contrast to what Oteiza considers silences that do not work [14]. Silence must be created, it is spatial [14]. In this sense Tribute to Bach can be a composition of silences. It can be a musical score for silence that includes notes of silence.

\section{Conclusion}

Oteiza studied and devoted himself to music much more than he managed to show or, perhaps, we have not been able to discover, as can happen with the analysis of works such as Tribute to Bach, where the title already hints at the musicality, at least conceptually, that it contains.

Oteiza uses the wall because it also allows him to integrate the variable "time", something that the statue does not allow. Tribute to Bach contains that movement related to time. His musical-plastic spelling, close to serialism, suggests a metaphysical musical score made with the language and elements of a sculptor. A silent, perhaps Pythagorean, music that seeks the spiritual and coincides with Bach's music.

When Oteiza created the work Tribute to Bach "he had not acquired his own musical skills for composition in the traditional sense" [12]. Oteiza draws graphics that resemble scores in graphic notation and indeterminate writing. He is in a position to propose a graphic representation of the sound event, but it is difficult to offer the score that the musician requires for his performance.

For Oteiza, all these musical techniques are closely related to his aesthetic thinking ${ }^{16}$, which will not only be developed in a special way in his mural compositions, but will also be very present in the whole of his work. Thus, many of his works will be based on the spatial development of certain minimal and elemental units, which he will subject to different treatments and modulations in his sculptures, grouping them into experimental series based on repetitions and variations of his elements, until finally finding a sculpture that supposes its conclusion or definitive version.

Oteiza understood early on the great value of music as an experimental field for his aesthetic investigations of time and space, and the affinities of musical methodologies with those of his own art. These affinities start either from simple formal units, with which he carried out different tests or plastic treatments, using techniques similar to repetitions and variations, or from arrangements of his ensembles or series successions as in music.

This sculptor is interested in the fact that this music is created from minimum units of sound, and that, with a temporal calculation or series development; they convert the sound into a space. Oteiza related, aesthetically and metaphysically, space with silence. For the sculptor, this relationship was only possible in the immobility of a void, "[...] silence must be created [...] it is spatial [...] only space is silence [...]" [11]. For Oteiza, this unity between the visual and the vocal, is not just about making space an image or sound a meaning, but also creating, with formal elements and references, gaps and absences in the thickness and extension of the wall. In this way, it develops wide zones of immobility and silence where different visual and spatial aspects coexist, with clear musical resonances [11], in a synesthetic relationship. Thus all these techniques and all these musical methods must serve to develop what the sculptor calls "spatialist serialism" [19].

\section{References}

[1] Miguéliz, I. (2019), La familia Huarte y Oteiza, Génesis de la abstracción en los murales de Jorge Oteiza, Cuadernos coleccionables del Museo, 29. Pamplona: Museo Universidad de Navarra.

[2] Ortiz-Echagüe, J. (2014), “Jorge Oteiza," in: S. Olmo, (ed.), Colección $\mathrm{M}^{\mathrm{a}}$ Josefa Huarte. Abstracción y modernidad. Pamplona: Museo Universidad de Navarra, p. 75, p. 70.

\footnotetext{
16 "Thinking about serialism is thinking the same way for all the arts". [11]
} 
[3] Roldán, J. F. and Martín, M. E. (2016), "Procesos de desmontaje, traslado e instalación de dos relieves de gran formato de Jorge Oteiza," in Conservación de Arte Contemporáneo. Madrid, Museo Nacional Centro de Arte Reina Sofía: Departamento de conservación, pp. 196-206.

[4] Oteiza, J. (1963), Quousque tandem...!, Ensayo de interpretación estética del alma vasca, $1^{\mathrm{a}}$ ed. Donostia/San Sebastián: Auñamendi, p. 330, p. 9.

[5] Oteiza, J. (2011), Ejercicios espirituales en un túnel. En busca y encuentro de nuestra identidad perdida. Alzuza: Fundación Museo Oteiza /Fundazio Museoa, p. 424.

[6] Martín, E. (2019), Jorge Oteiza y el espacio mural. Génesis de la abstracción en los murales de Jorge Oteiza, Cuadernos coleccionables del Museo, 29. Pamplona: Museo Universidad de Navarra, p. 5, p. 4, p. 13.

[7] López-Bahut, E. (2014), Oteiza arquitectónico. Alzuza: Fundación Museo Jorge Oteiza, p. 42, p. 44, p. 164.

[8] Oteiza, J. (2007), Propósito experimental 1956-1957. Reedición facsímil del original Escultura de Oteiza. Catálogo. IV Bienal de São Paulo, 1957. Alzuza: Fundación Museo Oteiza /Fundazio Museoa.

[9] Lizasoáin, J. (2019), El muro de Jorge Oteiza. Un sistema para proyectar en el espacio. Alzuza: Fundación Museo Oteiza /Fundazio Museoa, p. 269.

[10] Pelay Orozco, M. (1978), OTEIZA su vida, su obra, su pensamiento, su palabra. Bilbao: La Gran Enciclopedia Vasca, p. 177, p. 418.

[11] Badiola, T. (2015), Oteiza. Catálogo razonado de escultura. vol II. Alzuza: Fundación Jorge Oteiza/Fundazio Museoa, p. 460.

[12] Etxebeste, E. (2014), Oteiza y la música. Alzuza: Fundación Museo Jorge Oteiza, p. 58 , p. 24 , p. 201 , p. 13 , p. 163 , p. 36 , p. 39 , p. 151 , p. 71 , p. 188 , p. 22 , p. 53 , p. 165 , p. 162 , p. 186 , p. 172 , p. 173 , p. 180 , p. 190 , p. 192 , p. 23 , p. 171 , p. 138 , p. 166 , p. 168 , p. 189 , p. 54 , p. 52 , p. 64 , p. 193.

[13] Fubini, E. (1999), La Estética Musical desde la Antigüedad hasta el Siglo XX, Madrid: Alianza, p. 429.

[14] AFMO (Archive of the Jorge Oteiza Museum Foundation, Alzuza, Navarra, Spain), FD-5214, FD 16566, FD9939, FD5272, F-11224, FD-9939, FD-5172, FD-16975.

[15] Oteiza, J. (1952), Interpretación estética de la estatuaria megalítica americana. Madrid: Cultura Hispánica. In: Muñoz, M. T. (ed.) (2007): Interpretación estética de la estatuaria megalítica americana. Carta a los artistas de América. Sobre el arte nuevo en la postguerra. Alzuza: Fundación Museo Jorge Oteiza, p. 283, p. 284.

[16] Albano de Lima, S. (2016), Las relaciones de la música con la cosmología, Epistemus, 4 (1), pp. 83-110, DOI: $10.21932 / 4.3057 .1$
[17] Fubini, E. (2004), El siglo XX: entre música y filosofía. Collecció estètica \& critica, 19. Valencia: Guada, p. 88.

[18] Rowell, L. (2005), Introducción a la Filosofía de la Música. Antecedentes Históricos y Problemas Estéticos, Barcelona: Gedisa.

[19] Oteiza, J. (1995), Estética del huevo. Huevo y Laberinto. Mentalidad Vasca y Laberinto. Pamplona: Pamiela, p. 47.

[20] Wedekind, G. (2019), "Un art peut en cacher un autre. Pierre Boulez beim Betrachten eines Aquarells von Paul Klee," in: Zenck, M., Oy-Marra, E., Pietschmann, K. and Wedekind, G. Intermedialität von Bild und Musik, pp. 394-412. DOI: https://doi.org/10.30965/9783846755594_028

[21] Von Maur, K. (1999), The Sound of Painting. Munich, London: Prestel.

[22] Monika, F. (2017). Polyphony in image and sound. Music in Art: International Journal for Music Iconography. Vol. 42 Issue 1/2, pp. 367-374.

[23] Johnson, S. (2011), The New York Schools of Music and the Visual Arts (Studies in Contemporary Music \& Culture). New York: Routledge, p. 1

\section{Biography}

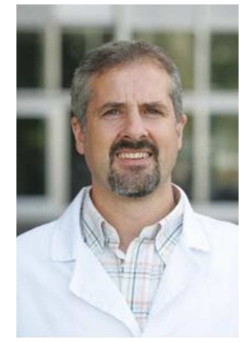

Fernando Echarri Iribarren holds a degree in Biological Sciences (University of Navarra, 1989) and a PhD in Environmental Education (University of Navarra, 2007). He teaches in the following areas: "Museum education", "Ecology", "Environmental Impact Assessment", "University Master's Degree in Higher-Education Teaching" and Master's Degree in "Biodiversity, Landscape and Sustainable Management". His interests include significant learning experiences and significant life experiences. He has published numerous books and articles on nature and art.

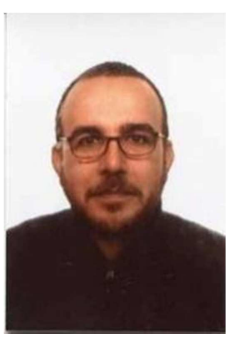

Emilio Varela Froján is an architect (1995), painter, poet and writer. $\mathrm{PhD}$ from the University of the Basque Country (UPV/EHU) - in Architecture for the programme "Idea, form and matter" (2011) and in Philosophy for the programme "Philosophy in a global world" (2015) -, has published and gave workshops on thought and creation and participated as a speaker in several international conferences on art and architecture. 